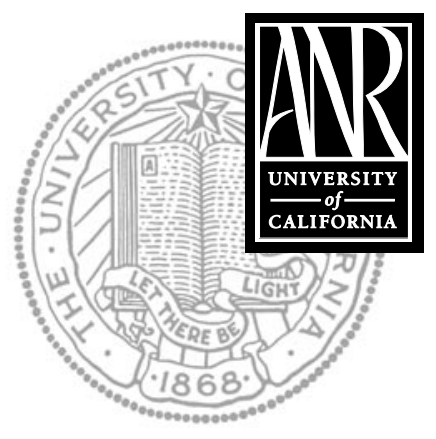

UNIVERSITY OF

CALIFORNIA

Division of Agriculture and Natural Resources http://anrcatalog.ucdavis.edu

\title{
Measuring Applied Water in Surface-Irrigated Orchards
}

\author{
LAWRENCE J. SCHWANKL, UC Cooperative Extension Irrigation Specialist; TERRY \\ L. PRICHARD, UC Cooperative Extension Water Management Specialist; BLAINE R. \\ HANSON, UC Cooperative Extension Irrigation and Drainage Specialist
}

The California State Water Code requires anyone discharging waste that could affect the waters of the state to obtain a permit or coverage under a waiver. Agricultural runoff, whether from irrigation or rainfall, that leaves a property has been determined likely to contain waste (sediment, nutrients, chemicals, etc.). Compliance under the Irrigation Lands Conditional Waiver is available to agricultural landowners who have runoff from their property caused by irrigation practices or winter rainfall. If no runoff from any source leaves a property, the California Water Code does not impact the property owner.

A major contributor to irrigation runoff can be water applied in excess of that required to refill the crop's root zone. Excess applied irrigation water may directly run off, or it may contribute to deep percolation losses below the crop's root zone. Deep percolation losses can degrade surface water quality under special hydrologic conditions where shallow groundwater is connected to surface waters.

Minimizing the application of excess water requires good irrigation scheduling (knowing when and how much water to apply) and knowing how much water is being applied by the irrigation system. For additional information on determining how much water to apply by estimating tree crop water use, see the companion publication Understanding Your Orchard's Water Requirements (ANR Publication 8212).

It is often difficult to measure the amount of water applied in surface irrigation systems. If water is delivered to the orchard in a pipeline, that pipeline is the easiest and most accurate location to make measurements. For additional information on how to measure pipeline flow rates, see Measuring Irrigation Flows in a Pipeline (ANR Publication 8213). It is more difficult and often less accurate to take flow measurements in an open ditch or canal system.

\section{SURFACE IRRIGATION SYSTEMS IN PERMANENT CROPS}

Among the many surface irrigation systems used in orchards are ditch and siphon systems (fig. 1), orchard "pot" systems (fig. 2), and alfalfa valve systems. In these systems, irrigation water is applied either by using furrows or by flooding the entire area between tree rows (border check flow system). Measuring the water flow once it is in the furrows or borders is difficult and is not recommended. The best opportunity for measurement is at the inflow point to the orchard.

This publication describes the following surface irrigation flow conditions and measurement techniques:

Ditch and siphon systems

- float-area method

- pipe trajectory

- siphon discharge rate

Orchard pot systems

- flow meter

- hand measurement

Alfalfa valve

- Temporary hydrant 
Figure 1. Orchard ditch and siphon system.

Photo: Lawrence J. Schwankl.

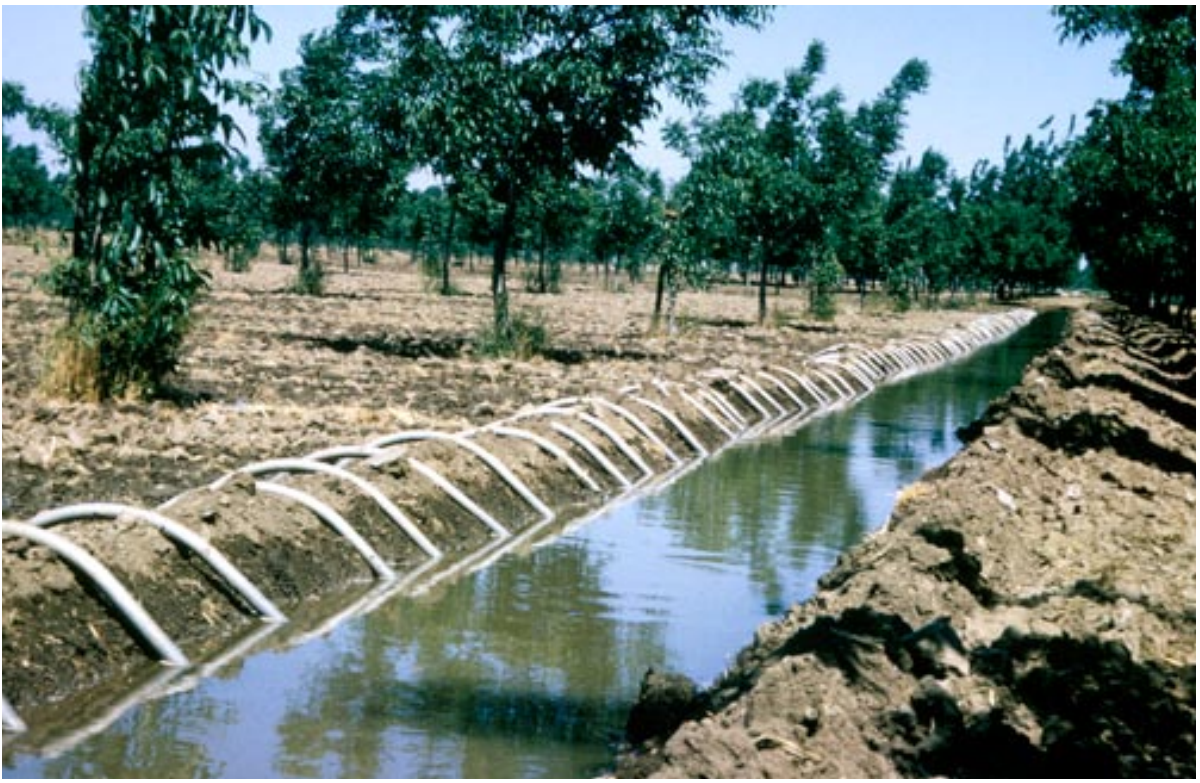

Each section below details how to determine the volume of applied irrigation water in acre-inches (ac-in). Another useful way of expressing applied water is in terms of the depth of water, inches in English units and millimeters or centimeters in metric units (for converting English units to metric units, see the table at the end of this publication). Expressing irrigation applications as a depth (inches) agrees well with rainfall information and crop water use (evapotranspiration) information, both of which are provided in inches.

To convert acre-inches of applied water to inches of applied water, use the following formula:

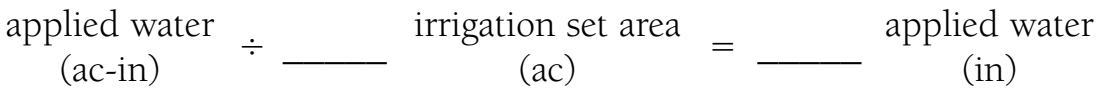

If the irrigation set area is not known, it can be determined by multiplying the field length by the irrigation set width and noting that 1 acre equals 43,560 square feet $\left(\mathrm{ft}^{2}\right)$.

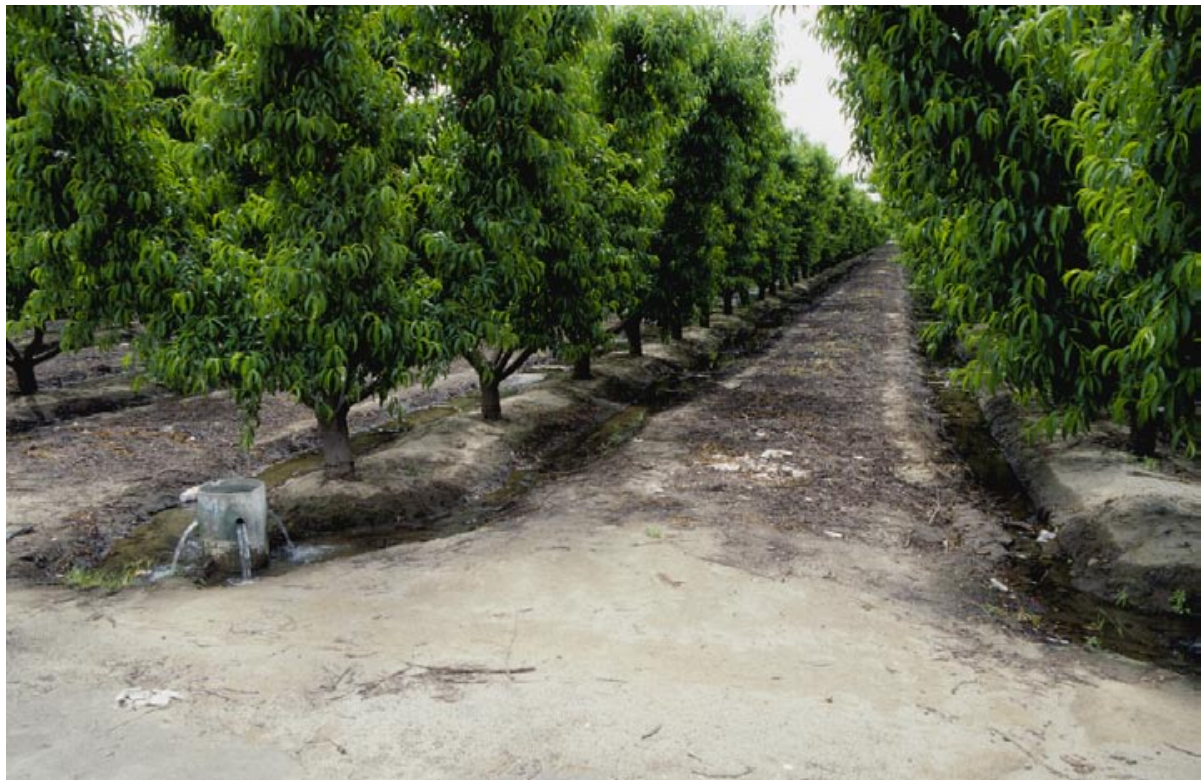

Figure 2. Orchard riser, or "pot," system.

Photo: Lawrence J. Schwankl. 


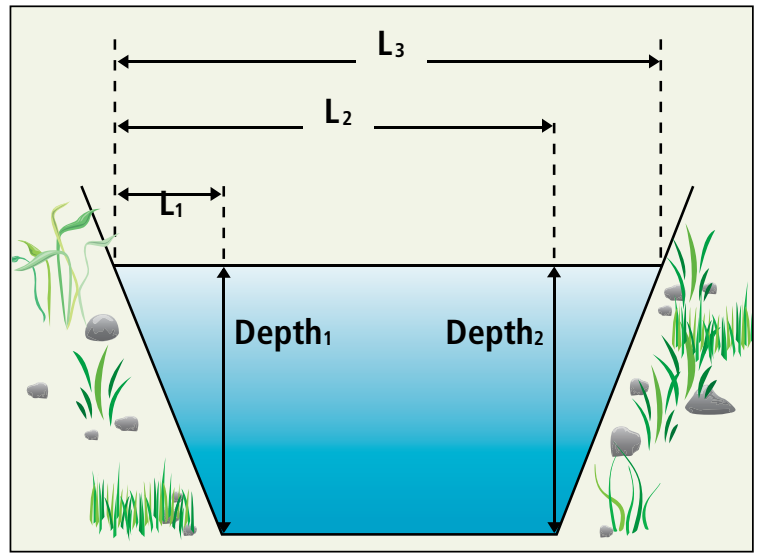

Figure 3. Measurement of channel cross-section.

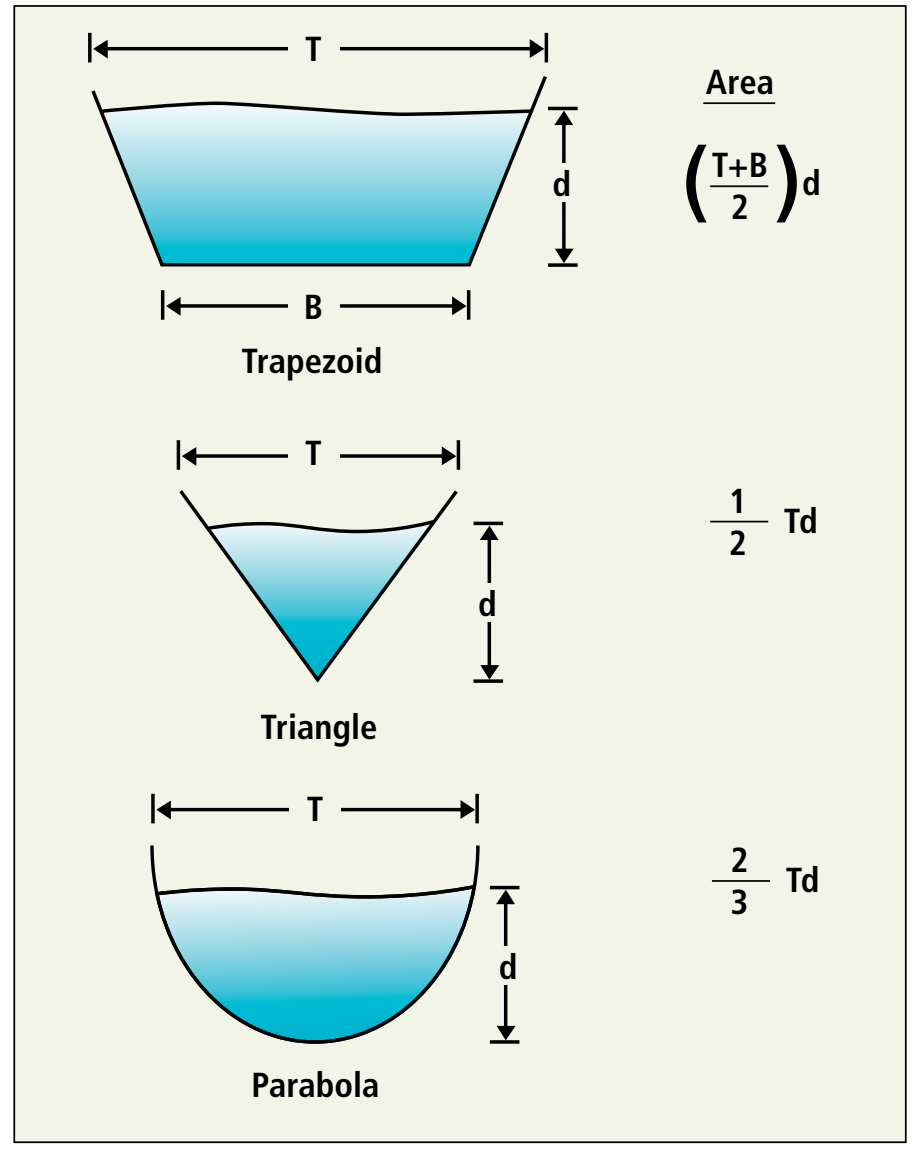

Figure 4. Cross-sectional area of common channel shapes.

\section{DITCH AND SIPHON SYSTEMS}

If the flow rate in the ditch is unknown, estimate either the ditch flow rate (float-area method), the pump discharge rate, or the siphon discharge rate.

\section{Float-area Method}

The float-area method requires measuring the cross-sectional area of the ditch and the amount of time it takes for a floating object to travel between two points in the ditch. This method provides only an estimate of the ditch flow rate, but it can be useful when other more accurate techniques are not available or practical. An example would be estimating the flow rate in a temporary head ditch that is used for only a few irrigations.

Select a straight section of ditch about 100 feet long where the width and depth are fairly uniform. Measure (in feet) and stake the distance between two locations. Determine the cross-sectional dimensions of the ditch at these points. The dimensions of the upstream and downstream cross-sections will be averaged and used later. If the ditch is very uniform, it will be necessary to determine the area of only one cross-section between the stakes.

A strong fiberglass extension ladder with a board fixed on top can be used as a bridge across the ditch. The top width of the channel can be measured by stretching a tape across the ditch. Most stream cross-sections are roughly triangular or trapezoidal in shape. The bottom and sides of the channel can be delineated by measuring the water depth at key locations from a measuring tape stretched across the top of the channel (fig. 3). These channel measurements can be used to determine the channel cross-sectional area in square feet. Figure 4 shows the formulas for determining the area of a number of common channel shapes. 
Table 1. Coefficients for converting float velocity to water velocity

\begin{tabular}{|l|c|}
\hline Average water depth $(\mathrm{ft})$ & Coefficient \\
\hline 1 & 0.66 \\
2 & 0.68 \\
4 & 0.70 \\
5 & 0.72 \\
6 & 0.74 \\
9 & 0.76 \\
12 & 0.77 \\
15 & 0.78 \\
20 and above & 0.79 \\
\hline
\end{tabular}

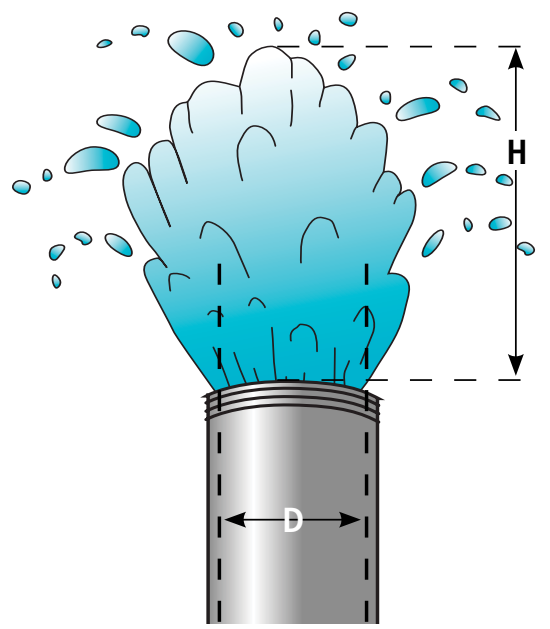

Figure 5. Vertical pipe trajectory flow measurement.

Place a float such as a stick or tennis ball in the channel well upstream of the first stake. This allows the float to reach flow velocity before it reaches the upstream stake. Record the time (in seconds) it takes for the float to move from the first stake to the second. The float should stay in the center of the channel and not touch the channel sides. Repeat the float test a number of times and average the travel times if needed.

Determine the float velocity in feet per second (ft/sec) by dividing the distance between the measurement stakes by the time it took the float to pass between the two stakes. Since the average water velocity is less than the float velocity, a correction coefficient (table 1) must be applied to the measured float velocity.

Finally, determine the channel flow rate in cubic feet per second (cfs) by multiplying the average water velocity ( $\mathrm{ft} / \mathrm{sec}$ ) by the average of the channel cross-sectional areas $\left(\mathrm{ft}^{2}\right)$ determined at the two stake locations. Note that $1 \mathrm{cfs}=449 \mathrm{gpm}$.

To determine the irrigation volume in acre-inches (ac-in) applied to the irrigation set from a given ditch, use the applicable formula below:

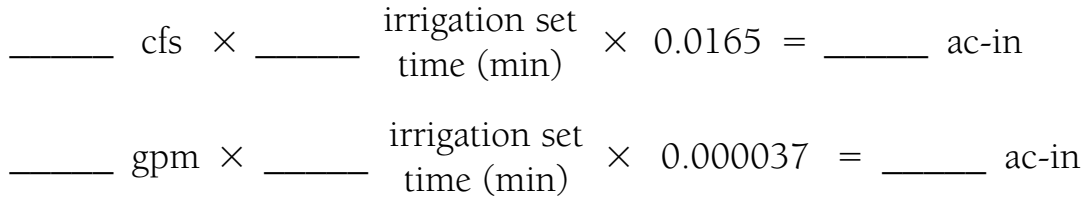

\section{Pipe Trajectory Method}

The pipe trajectory method can be used to estimate the flow rate from a pump discharge. For vertical pipes, measure the pipe's inside diameter (D) and the height water rises above the end of the pipe (H) (fig. 5). Use table 2 to determine the flow rate from a vertical pipe (gpm). For horizontal pipes, measure the pipe's inside diameter (D) and the distance of the trajectory (X) of the discharge water (fig. 6). Use table 3 to determine the pipe discharge in gallons per minute (gpm).

To determine the water applied in acre-inches (ac-in) to the irrigation set from a given pipe, use the following formula:

$$
\text { pipe discharge rate } \times
$$
(gpm) irrigation set time (min) applied water (ac-in)

\section{Siphon Discharge Rate}

The discharge rate from an individual siphon can also be estimated by measuring the difference in water surface heights between the water in the ditch and the water in the field just downstream of the siphon. This difference in water levels is often called the "head" (fig. 7). Use figure 8 to determine the siphon pipe discharge (gpm).

To determine the water applied in acre-inches (ac-in) to the irrigation set, use the following formula:

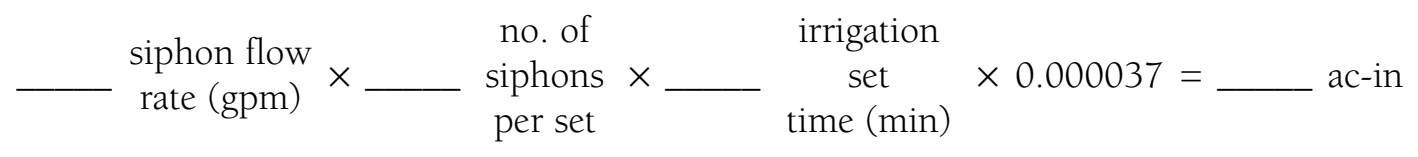


Table 2. Flow from vertical pipe (gpm)

\begin{tabular}{|c|c|c|c|c|c|c|c|c|}
\hline \multirow{2}{*}{$\begin{array}{l}\text { Jet height, } \\
\text { H (in) }\end{array}$} & \multicolumn{8}{|c|}{ Inside diameter of pipe (in) } \\
\hline & 2 & 3 & 4 & 5 & 6 & 8 & 10 & 12 \\
\hline 2 & 28 & 57 & 86 & 115 & 150 & 215 & 285 & 355 \\
\hline 2.5 & 31 & 69 & 108 & 150 & 205 & 290 & 385 & 480 \\
\hline 3 & 34 & 78 & 128 & 182 & 250 & 367 & 490 & 610 \\
\hline 3.5 & 37 & 86 & 145 & 210 & 293 & 440 & 610 & 755 \\
\hline 4 & 40 & 92 & 160 & 235 & 330 & 510 & 725 & 910 \\
\hline 4.5 & 42 & 98 & 173 & 257 & 365 & 570 & 845 & 1,060 \\
\hline 5 & 45 & 104 & 184 & 275 & 395 & 630 & 940 & 1,200 \\
\hline 6 & 50 & 115 & 205 & 306 & 445 & 730 & 1,125 & 1,500 \\
\hline 7 & 54 & 125 & 223 & 336 & 485 & 820 & 1,275 & 1,730 \\
\hline 8 & 58 & 134 & 239 & 360 & 521 & 890 & 1,420 & 1,950 \\
\hline 9 & 62 & 143 & 254 & 383 & 550 & 955 & 1,550 & 2,140 \\
\hline 10 & 66 & 152 & 268 & 405 & 585 & 1,015 & 1,650 & 2,280 \\
\hline 12 & 72 & 167 & 295 & 450 & 650 & 1,120 & 1,830 & 2,550 \\
\hline 14 & 78 & 182 & 320 & 485 & 705 & 1,220 & 2,000 & 2,800 \\
\hline 16 & 83 & 195 & 345 & 520 & 755 & 1,300 & 2,140 & 3,000 \\
\hline 18 & 89 & 208 & 367 & 555 & 800 & 1,400 & 2,280 & \\
\hline 20 & 94 & 220 & 388 & 590 & 850 & 1,480 & 2,420 & \\
\hline 25 & 107 & 248 & 440 & 665 & 960 & 1,670 & 2,720 & \\
\hline 30 & 117 & 275 & 485 & 740 & 1,050 & 1,870 & 3,000 & \\
\hline 35 & 127 & 300 & 525 & 800 & 1,150 & 2,020 & & \\
\hline 40 & 137 & 320 & 565 & 865 & 1,230 & 2,160 & & \\
\hline
\end{tabular}

Note: For pipe inside diameters other than those shown in the table, interpolate values between the closest given values.

Table 3. Discharge rate (gpm) for a horizontal pipe with a vertical water trajectory of 4 inches

\begin{tabular}{|c|c|c|c|c|c|c|c|c|}
\hline \multirow{2}{*}{$\begin{array}{l}\text { Horizontal } \\
\text { distance, X (in) }\end{array}$} & \multicolumn{8}{|c|}{ Nominal pipe diameter (in) } \\
\hline & 3 & 4 & 5 & 6 & 8 & 10 & 12 & $\begin{array}{c}\text { Average } \\
\text { velocity (ft/sec) }\end{array}$ \\
\hline 4 & 48.5 & 83.5 & & & & & & 2.1 \\
\hline 5 & 61.0 & 104.0 & 163 & & & & & 2.6 \\
\hline 6 & 73.0 & 125.0 & 195 & 285 & & & & 3.1 \\
\hline 7 & 85.0 & 146.0 & 228 & 334 & 580 & & & 3.7 \\
\hline 8 & 97.5 & 166.0 & 260 & 380 & 665 & 1,060 & & 4.2 \\
\hline 9 & 110.0 & 187.0 & 293 & 430 & 750 & 1,190 & 1,660 & 4.7 \\
\hline 10 & 122.0 & 208.0 & 326 & 476 & 830 & 1,330 & 1,850 & 5.3 \\
\hline 11 & 134.0 & 229.0 & 360 & 525 & 915 & 1,460 & 2,200 & 5.8 \\
\hline 12 & 146.0 & 250.0 & 390 & 570 & 1,000 & 1,600 & 2,200 & 6.2 \\
\hline 13 & 158.0 & 270.0 & 425 & 620 & 1,080 & 1,730 & 2,400 & 6.9 \\
\hline 14 & 170.0 & 292.0 & 456 & 670 & 1,160 & 1,860 & 2,590 & 7.4 \\
\hline 15 & 183.0 & 312.0 & 490 & 710 & 1,250 & 2,000 & 2,780 & 7.9 \\
\hline 16 & 196.0 & 334.0 & 520 & 760 & 1,330 & 2,120 & 2,960 & 8.4 \\
\hline 17 & 207.0 & 355.0 & 550 & 810 & 1,410 & 2,260 & 3,140 & 9.1 \\
\hline 18 & 220.0 & 375.0 & 590 & 860 & 1,500 & 2,390 & 3,330 & 9.7 \\
\hline 19 & 232.0 & 395.0 & 620 & 910 & 1,580 & 2,520 & 3,500 & 10.4 \\
\hline 20 & 244.0 & 415.0 & 650 & 950 & 1,660 & 2,660 & 3,700 & 10.6 \\
\hline 21 & 256.0 & 435.0 & 685 & 1,000 & 1,750 & 2,800 & & 11.4 \\
\hline 22 & & 460.0 & 720 & 1,050 & 1,830 & 2,920 & & 11.8 \\
\hline 23 & & & 750 & 1,100 & 1,910 & 3,060 & & 12.4 \\
\hline 24 & & & & 1,400 & 2,000 & 3,200 & & 13.0 \\
\hline
\end{tabular}




\section{ORCHARD POT SYSTEMS}

Concrete risers, or "pots," connected to an underground pipeline are often used to irrigate orchards and vineyards. The riser contains an adjustable valve, and it may also have slide gates that can also be adjusted (fig. 2). Two methods of flow measurement can be used under these conditions: either a flow meter can be installed in the pipeline or water can be measured manually as it discharges from the risers.

\section{Using a Flow Meter}

The easiest flow measurement method is to install a flow meter in the pipeline upstream of the field. A propeller meter works very well. Installing a flow meter in the low-head concrete or plastic pipeline can be expensive if the pipeline has a large diameter. For plastic pipeline it may be possible to measure the flow rate using a portable Doppler flow meter temporarily strapped to the pipe's outer wall.

Having a flow meter at the water source may also be an option, especially if the water source is pumped from groundwater or an irrigation canal. The diameter of the pump discharge pipe is usually well suited for a flow meter. A complication to this method is where multiple water sources are used (e.g., multiple wells), and a number of fields are being irrigated simultaneously. In this instance, it may be difficult to determine the flow to an individual field.

If the flow meter indicates both instantaneous flow rate (i.e., gallons per minute, gpm) and totalized flow (i.e., gallons, acre-feet, or acre-inches), use totalized flow readings taken at the beginning and end of the irrigation set to determine the applied water. Using totalized flows is more accurate than using instantaneous flow rates. Use the appropriate formula below to fit your condition.

If your totalized flow is already in acre-inches, leave it in that form. For totalized flow measurements:

$$
\begin{aligned}
& \text { gal } \times 0.000037=\ldots \text { ac-in } \\
& \text { ac-ft } \times 12=\ldots \text { ac-in }
\end{aligned}
$$

If only instantaneous flow rates are available, use the appropriate formula below:

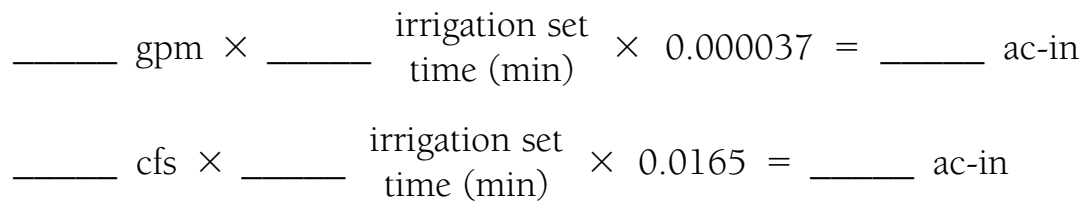

\section{Hand-measurement of Discharge}

If you do not have a flow meter in the pipeline, your remaining flow measurement option is to manually collect water coming out of the side of the riser. This is done using a bucket and stopwatch to determine the flow rate from the jet being monitored. The following formula can be used to make this calculation:

$$
\begin{gathered}
\text { water collected } \\
\text { (gal) }
\end{gathered} \div \ldots \begin{gathered}
\text { collection time } \\
(\mathrm{sec})
\end{gathered} \times 60 \mathrm{sec} / \mathrm{min}=\ldots \begin{gathered}
\text { discharge } \\
\text { rate } \\
(\mathrm{gpm})
\end{gathered}
$$

For example, if it took 20 seconds to fill a 5-gallon pail, the discharge rate (gpm) would be

$$
5 \text { gallons } \div 20 \text { seconds } \times 60=15 \text { gpm }
$$




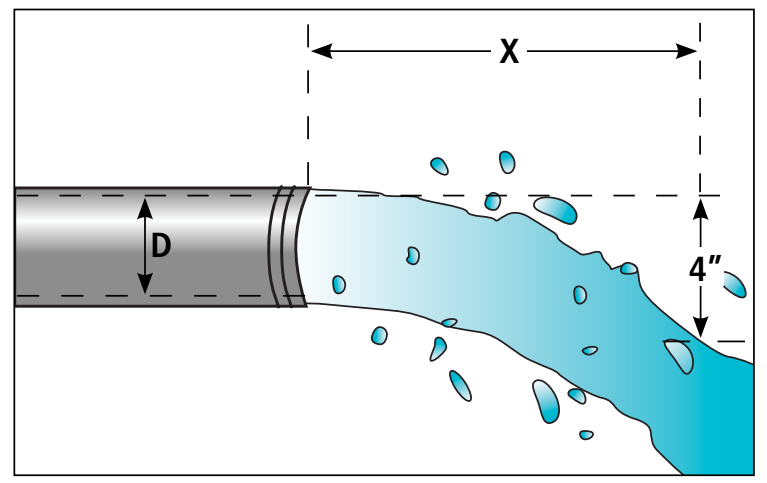

Figure 6. Horizontal pipe trajectory flow measurement.

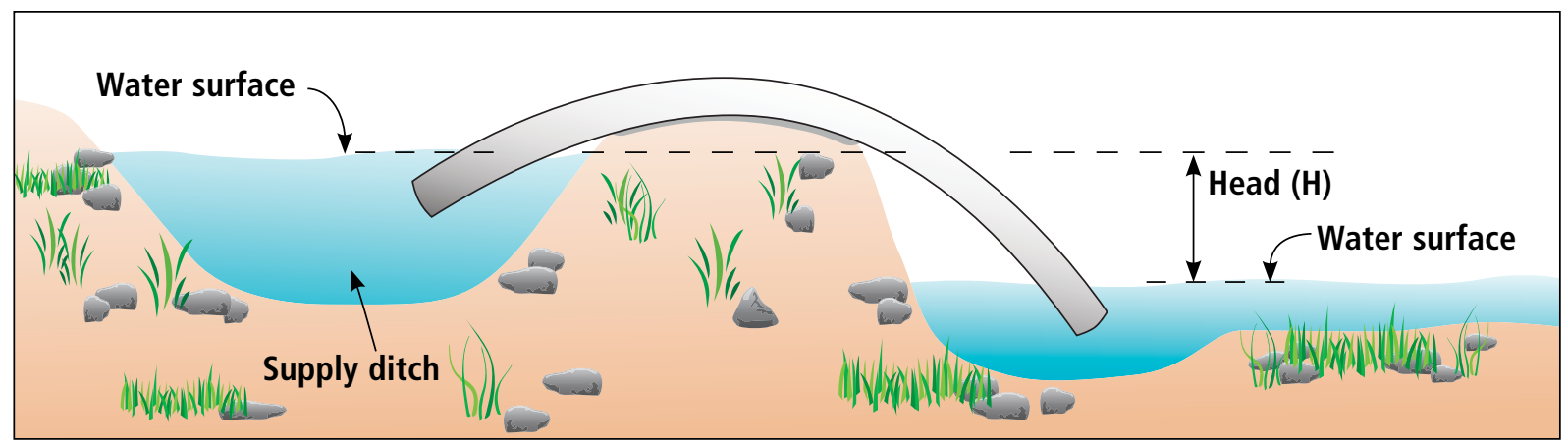

Figure 7. Determining the head $(\mathrm{H})$ difference in siphon pipe irrigation.

Rate of flow through small siphons

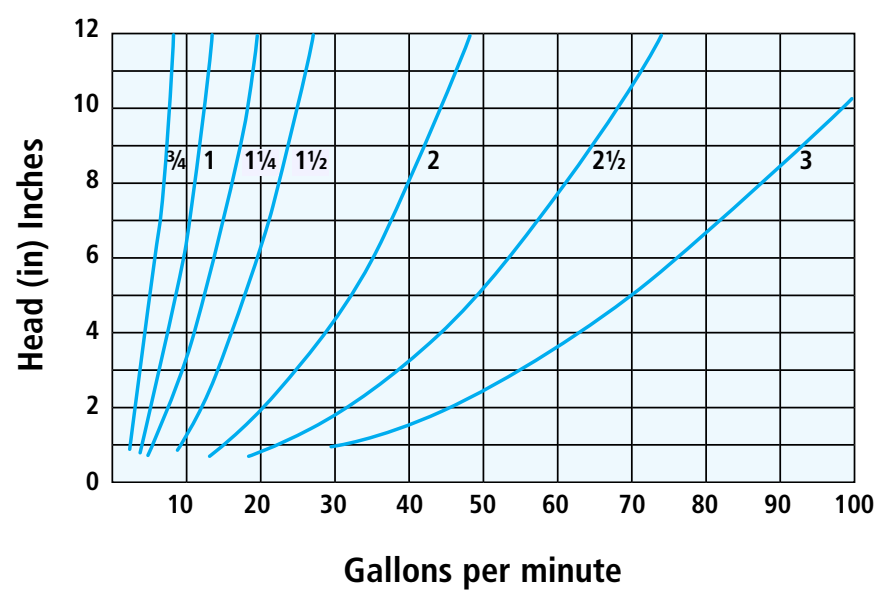

Rate of flow through large siphons

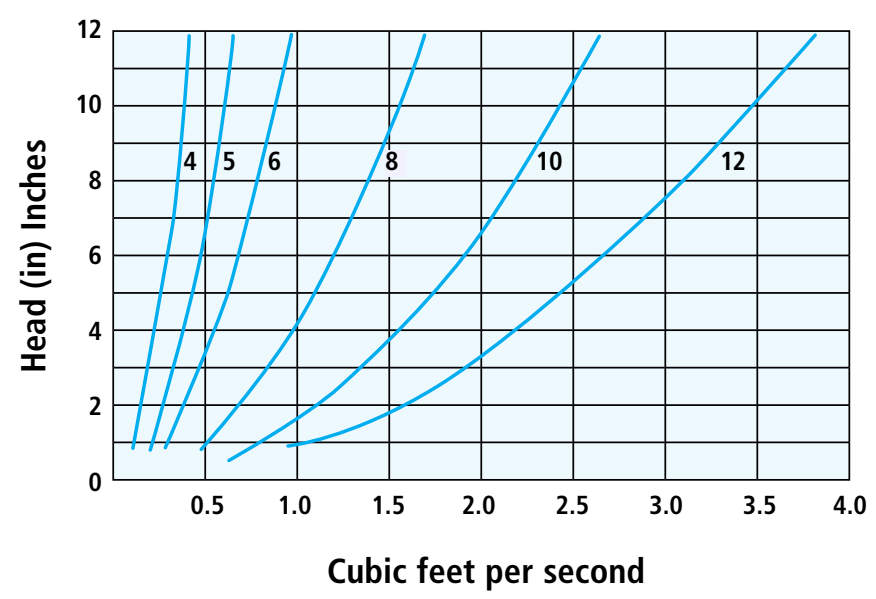

Figure 8. Discharge rate from siphon pipes. Note that $1 \mathrm{cfs}=448 \mathrm{gpm}$. Source: V. H. Scott and C. E. Houston, Measuring Irrigation Water (Oakland: University of California Division of Agriculture and Natural Resources Leaflet 2956, 1981), p. 21. 
The discharge rate should be measured from as many risers as possible. You will soon determine whether there is a significant difference between riser discharge rates and all risers must be measured, or whether there is consistency between riser discharge rates and only a sampling is needed.

Determine the flow rate to the irrigation set using the following formula:

$$
\begin{gathered}
\text { gate discharge } \\
\text { rate }(\mathrm{gpm})
\end{gathered} \times \begin{gathered}
\text { no. of gates in } \\
\text { irrigation set }
\end{gathered}=\ldots \begin{gathered}
\text { applied water } \\
(\mathrm{gpm})
\end{gathered}
$$

Determine the total applied water (ac-in) using the following formula:

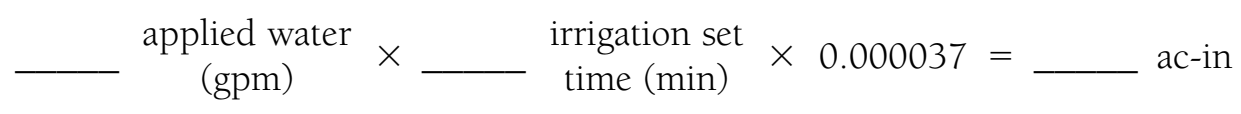

\section{ALFALFA VALVE SYSTEMS}

As with orchard pot systems, alfalfa valve systems use a concrete or PVC pipeline to deliver the water to the orchard. If a propeller meter can be installed in the pipeline, it is the best way to measure the flow. Measuring the discharge from an alfalfa valve is difficult but can be done using the following technique.

\section{Temporary Hydrant}

A temporary hydrant with a flow meter installed over an alfalfa valve can be used to measure the applied water. See figure 9 for a schematic of this technique.

The flow meter is installed in the section of pipe extending out of the side of the hydrant. This flow meter can be a propeller meter or a Doppler meter temporarily mounted to the side of the horizontal pipe. For details on calculations, see the section "Orchard Pot Systems-Using a Flow Meter," above.

\section{WHAT IF IRRIGATION RUNOFF IS A PROBLEM?}

Once the amount of applied water for an irrigation is measured, it is often found that the amount is greater than what is needed to replace the water used by the trees since the last irrigation. The excess water will either percolate deep below the tree root zone or run off from the orchard.

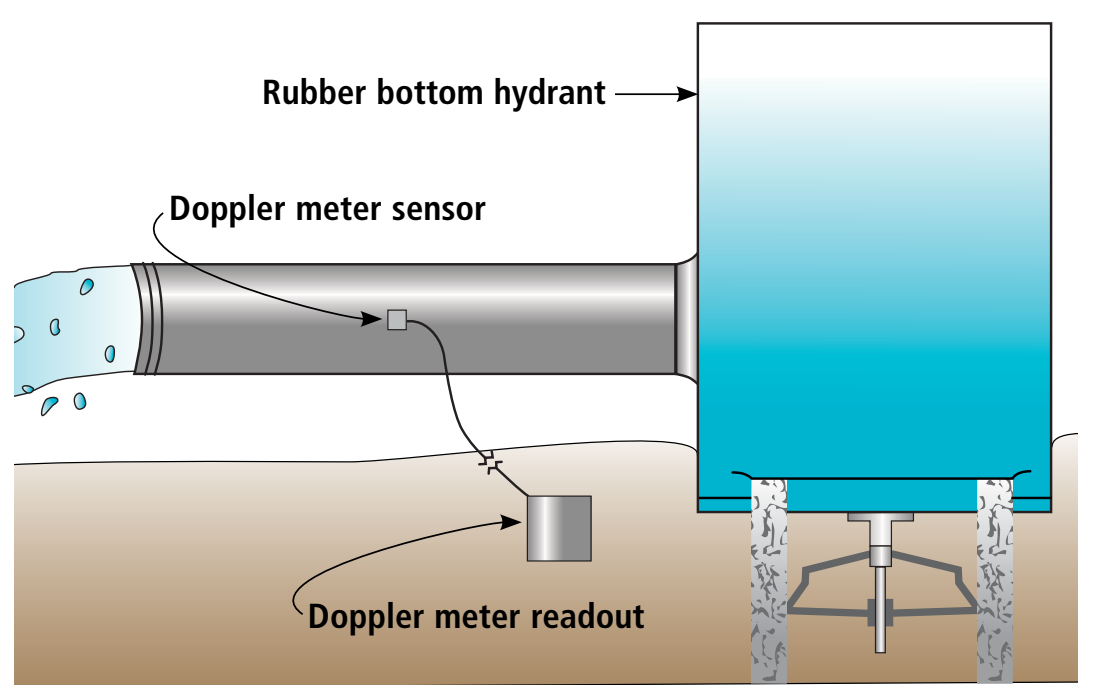

Figure 9. Temporary hydrant installed over an alfalfa valve to measure the flow rate.
Currently, the emphasis of the Irrigated Lands Discharge Waiver Program is focused on irrigation runoff to surface waters and its impact on water quality. If tailwater is being generated and it is running off the property, there are a number of steps which can be taken. First, determine whether the irrigation set can be managed to decrease the tailwater amount. Could the irrigation water be turned off sooner to minimize tailwater while still adequately irrigating the tail end of the orchard? 
Second, consider installing a tailwater return system. This system, often used with surface irrigation in row and field crops, collects runoff at the end of a field and reuses it for irrigation. It eliminates irrigation runoff and is an excellent management practice. For more information on tailwater return systems, see the companion publication Tailwater Return Systems (ANR Publication 8225). Additional information on handling irrigation runoff from the orchard can be found in the publication Causes and Management of Runoff from Surface Irrigation in Orchards (ANR Publication 8214).

\section{METRIC CONVERSIONS}

\begin{tabular}{|l|c|c|l|}
\hline English & $\begin{array}{l}\text { Conversion factor for } \\
\text { English to Metric }\end{array}$ & $\begin{array}{l}\text { Conversion factor for } \\
\text { Metric to English }\end{array}$ & Metric \\
\hline foot (ft) & 0.3048 & 3.28 & meter (m) \\
\hline square foot (ft²) & 0.0929 & 10.764 & square meter $\left(\mathrm{m}^{2}\right)$ \\
\hline cubic foot (ft $\left.{ }^{3}\right)$ & 28.317 & 0.353 & liter (l) \\
\hline acre (ac) & 0.4047 & 2.471 & hectare (ha) \\
\hline acre-inch (ac-in) & 102.8 & 0.00973 & cubic meter $\left(\mathrm{m}^{3}\right)$ \\
\hline acre-foot (ac-ft) & $1,233.0$ & 0.000811 & cubic meter $\left(\mathrm{m}^{3}\right)$ \\
\hline pounds per square inch (psi) & 6.894 & 0.145 & kilopascal $(\mathrm{kPa})$ \\
\hline gallon (gal) & 3.785 & 0.264 & liter $(\mathrm{l})$ \\
\hline
\end{tabular}

\section{FOR FURTHER INFORMATION}

Storing Runoff from Winter Rains (ANR Publication 8211), 2007.

Understanding Your Orchard's Water Requirements (ANR Publication 8212), 2007.

Measuring Irrigation Flows in a Pipeline (ANR Publication 8213), 2007.

Causes and Management of Runoff from Surface Irrigation in Orchards (ANR Publication 8214), 2007.

Managing Existing Sprinkler Irrigation Systems (ANR Publication 8215), 2007.

Soil Intake Rates and Sprinkler Application Rates in Sprinkler-Irrigated Orchards (ANR Publication 8216), 2007.

Tailwater Return Systems (ANR Publication 8225), 2007.

To order or obtain printed ANR publications and other products, visit the ANR Communication Services online catalog at http://anrcatalog.ucdavis.edu. You can also place orders by mail, phone, or FAX, or request a printed catalog of our products from:

University of California

Agriculture and Natural Resources

Communication Services

6701 San Pablo Avenue, 2nd Floor

Oakland, California 94608-1239

Telephone: (800) 994-8849 or (510) 642-2431

FAX: (510) 643-5470

E-mail inquiries: danrcs@ucdavis.edu

An electronic version of this publication is available on the ANR Communication Services Web site at http://anrcatalog.ucdavis.edu.

Publication 8230 


\section{$\bigcup_{P \in R M}$ REVIEWED}

ISBN 13: 978-1-60107-450-8

(C) 2007 by the Regents of the University of California, Division of Agriculture and Natural Resources. All rights reserved.

The University of California prohibits discrimination or harassment of any person on the basis of race, color, national origin, religion, sex, gender identity, pregnancy (including childbirth, and medical conditions related to pregnancy or childbirth), physical or mental disability, medical condition (cancer-related or genetic characteristics), ancestry, marital status, age, sexual orientation, citizenship, or status as a covered veteran (covered veterans are special disabled veterans, recently separated veterans, Vietnam era veterans, or any other veterans who served on active duty during a war or in a campaign or expedition for which a campaign badge has been authorized) in any of its programs or activities. University policy is intended to be consistent with the provisions of applicable State and Federal laws.

Inquiries regarding the University's nondiscrimination policies may be directed to the Affirmative Action/Staff Personnel Services Director, University of California, Agriculture and Natural Resources, 1111 Franklin Street, 6th Floor, Oakland, CA 94607-5201 (510) 987-0096. For a free catalog of other publications, call (800) 994-8849. For help downloading this publication, call (530) 754-5112.

This publication has been anonymously peer reviewed for technical accuracy by University of California scientists and other qualified professionals. This review process was managed by the ANR Associate Editor for Land, Air, and Water Sciences.

pr-8/07-SB/RW 